\title{
The womb: a site of domination and resistance in the Pre-emancipation British Caribbean
}

\section{Collin Xia 2 T1}

York University

Faculty of Graduate Studies, Department of Political Science

\section{A B S T R A C T}

Beginning in the 1780s, British Caribbean plantocracies faced the looming threat of slave trade abolition which would end the flow of enslaved African labour to Caribbean plantation colonies. An enslaved woman's function as the source of blackness and legal slave status made their wombs essential to a future without readily available slave imports. Narratives centring the intensifying colonial domination of enslaved women's wombs highlight abolitionists and slave owners' deployment of enslave women's reproductive labour in slave-breeding programs to produce a self-sustaining source of labour. This narrative neglects the agency enslaved women exerted in exacting control over their sexuality, marriage status, pregnancies, childbirth experience, and child-rearing process that jeopardised the institution of slavery in "gynecological revolt." This essay privileges the feminized, unarmed, sexual, bodily defiance of enslaved women within the greater, often masculinized Caribbean slavery scholarship to argue that the womb was a site of intensifying colonial domination in the Age of Abolition but more significantly a site of women's revolutionary struggle against slavery.

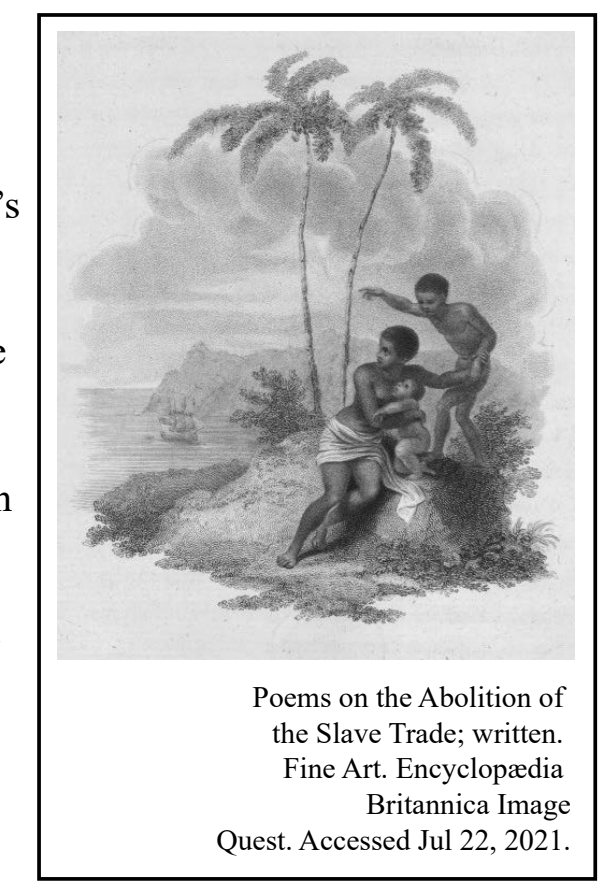

Keywords: British Caribbean, Jamaica, enslaved women, British slave abolition, biological reproduction, Atlantic slave trade, gynecological revolt, the womb

\section{B I O}

Collin Xia is a graduate of the University of Toronto's International Relations program and Master's Student at York University's Political Science Department. His research interests include Queer International Relations, Settler-Colonialism, and the Black Diaspora

Caribbean Studies Students'Union, Canada - https://jps.library.utoronto.ca/index.php/cquilt/ 
Women's bodies and labour have been at the heart of colonial monoculture export economies and the entire racial slavery system. ${ }^{1}$ They were "important sites of political struggles over slavery, abolition, and colonial reform," as their sexuality, reproductive labour, and childrearing practices acted as zones of conflict, in which abolitionists, slaveholders, the imperial government, and enslaved people competed to control.' Enslaved women's reproductive labour held symbolic and legal significance in British colonial societies as their bodies reproduced "blackness" and its "enslavability," allowing slave owners to claim the offspring of their female slaves as their property. It was not until the 1780 s, the beginning of the British abolition campaign, in which slave owners foresaw an existential threat to the plantocracy and sought to fully capitalize on the womb to sustain the colonial-slave system. ${ }^{4}$ From that point on, Anglo-Caribbean plantocracies demonstrated significant interest in enslaved women's reproductive labour to manage slave demographics but enslaved women often defied their masters to exert control over their reproductive capacities in "gynecological revolt",

This essay examines sources centred on Jamaica to argue that the wombs of enslaved women in the Anglo-Caribbean colonies were sites of colonial domination as slaveowners, abolitionists, and the imperial government fought to control it but were also sites of "gynecological revolt" as women exerted control over their sexuality, pregnancy, childbirth experience, and child-rearing process. The first section of this essay will describe the legal and ideological struggle between British abolitionists and slaveowners over slave trade abolition from the 1780 s to 1807. The debate sparked increased control over women's reproductive capacities as abolitionists sought to frame women as the source of a self-replenishing labour force that justified the abolition ${ }^{2}$ of the slave trade. As abolitionists gained momentum in Britain, slaveowners began slave breeding projects to secure a new source of labour for a future without readily available slave imports. The second section begins to unravel the narrative that British intellectuals, parliamentarians, and humanitarians were the sole force fighting against the slave system by centring enslaved women who challenged slavery by exerting control over their bodies and reproduction. Finally, the conclusion will tie this investigation of reproductive resistance together and make concluding comments on the lack of significance slave scholarship places on women's feminized, unarmed, sexual, bodily defiance.

To begin a discussion on women's gynecological revolt during Britain's Age of Abolition (defined in this research as the 1760s-1833 ), abolitionist strategies to abolish the slave trade and slavery

\footnotetext{
${ }^{1}$ Jennifer L. Morgan, Laboring Women: Reproduction and Gender in New World Slavery (Philadelphia: University of Pennsylvania Press, 2004), 4.

${ }^{2}$ Sasha Turner, Contested Bodies: Pregnancy, Childrearing, and Slavery in Jamaica (Philadelphia: University of Pennsylvania Press, 2017), 10.

${ }^{3}$ Morgan, Laboring Women, 1.

${ }_{5}^{4}$ Turner, Contested Bodies, 18.

${ }^{5}$ Morgan, Laboring Women, 11.
} 
employing women's reproductive capacity must be examined in relation to slaveowner's interests in preserving the status quo. According to Sasha Turner, before the emergence of the abolitionist movement, slaveowners preferred male slaves who were thought to be "more versatile and capable of performing the sugar plantations' variously demanding agro-industrial tasks." ${ }^{6}$ On the other hand, slaveholders "reluctantly bought females for their Jamaican sugar estates throughout the seventeenth century and maintained this practice until the late eighteenth century" as enslaved women were considered less valuable due to their physiological needs during and after pregnancies, which were "viewed as distractions by capitalistic planters whose main focus was maintaining productivity and profitability." 7

Women's symbolic role in reproducing the slave status through their reproductive labour was not as valued because it was more profitable to purchase a male adult at their physical prime than accommodate women's pregnancies and raise their children. It was not until the 1780s when slaveowners began to reconsider the profitability of women's reproductive labour as the abolitionist campaign began successfully lobbying the end of the slave trade. The abolition of the slave trade, (abolitionist activists' first step in abolishing slavery in the British Empire), strategically employed enslaved women's reproductive labour to advocate for a racial eugenics program that would supposedly make slave trading obsolete and sustain the plantation economy. ${ }^{8}$ Abolitionists "mobilized a particular racial violence against black sexuality and motherhood" in which control of enslaved women's fertility and maternity were central to creating a free labouring population that could be molded into ideal subject-citizens of the empire. ${ }^{9}$ While most Jamaican slaveowners rejected the notion that their slaves could be reformed into equally free subjects, they changed theîr slave purchasing patterns to select more women of child-bearing age to achieve sex-parity and began a plantation breeding program to secure an alternative labour force! ${ }^{10}$ Overall, the success of the movement to abolish British slave trading was hinged on a program to control black women's reproductive labour to reproduce a "working population suitable for building and sustaining the British imperial enterprise."11As Turner rẻflects, "whether in slavery or antislavery rhetoric, black women's bodies and their lives were defined by their ability to propagate workers for the colonial economy." era of abolition paradoxically ushered in a period of anxiety fuelled violence and control over a previously neglected resource, the womb.

The narrative of the abolitionist-plantocracy struggle over enslaved women's reproductive capacities to secure a stable post-slave trade labour force is significant

\footnotetext{
8 Turner, "Home-grown Slaves," 39-40.

9 Turner, "Home-grown Slaves," 42.

${ }^{10}$ Turner, Contested Bodies, 23; Turner, "Home-grown Slaves," 42.

${ }^{11}$ Turner, "Home-grown Slaves," 43.

12Turner, "Home-grown Slaves," 42
} 
but not inclusive of the power and agency enslaved women exercised in this transition period by sabotaging the abolitionist-plantocracy slave breeding project. One aspect of this project was the attempt by both abolitionists and slave owners to encourage monogamous slave marriages that would subjugate female sexuality under the institution of marriage and produce racially "pure" slave children. However, enslaved women engaged in gynecological resistance by rejecting monogamy, having interracial relationships that granted them privileged status in the plantation hierarchy, as well as liberating their bodies from sexual/reproductive slavery through marronage. Despite their conflicting objectives, many slaveowners, policymakers, and abolitionists found common ground in using marriage as an institution that would encourage slave reproduction, control slave sexuality through the practice of monogamy, and preserve racial purity and hierarchy in colonies. ${ }^{13}$

In Katherine Paugh's article, "The Curious Case of Mary Hylas: Wives, Slaves and the Limits of British Abolitionism," the institution of marriage and slavery are revealed to share a loss of civil identity for married women and slaves, a kind of "social death" that made enslaved women resistant to marriage!4Rhonda Reddock further argues that the contempt for marriage among slave women was because "it meant extra work and being confined to one man" when both men and women often maintained multiple relationships.$^{15}$ Moreover, enslaved women actively resisted abolitionist and slaveowner interests in"cultivating a purely African plantation labour force" by having sex with non-African men which at times conferred elite status for themselves and their mixed-race children. Paugh asserts that the sexual economies of British slave societies "could foster vastly unequal and even violently exploitative relationships between white men and Afro-Caribbean women," but interracial reproduction also provided rare opportunities for some enslaved women to "carve out a relative independence" from husbands, masters, and abolitionists. 16

While some enslaved women enjoyed privileged lives by rejecting racial sex restrictions, some women's path to gynecological revolt was through marronage. Verene Shepherd asserts that many women did not give their bodies for reproduction or sex and chose marronage to remove their bodies "from the site of oppression." "17 By viewing marronage as a form of gynecological revolt, these women removed their wombs from colonial control. They removed an asset that reproduced slaves and created wealth for slaveowners. Their liberated bodies could then engage in sexual activity and reproductive labour outside the institution of

\footnotetext{
${ }^{13}$ Katherine Paugh, "The Curious Case of Mary Hylas: Wives, Slaves and the Limits of British Abolitionism," Slavery \& Abolition 35, no. 4 (October 2, 2014): 643.

${ }^{14}$ Paugh, "The Curious Case of Mary Hylas," 629-630.

${ }^{15}$ Rhoda E. Reddock, "Women and Slavery in the Caribbean: A Feminist Perspective," Latin American Perspectives 12, no. 1 (January 1985): 69.

${ }^{16}$ Paugh, "The Curious Case of Mary Hylas," 647

${ }^{17}$ Verene A. Shepherd, "Women and the Abolition Campaign in the African Atlantic," The Journal of Caribbean History 42, no. 1 (2008): 139

${ }^{18}$ Shepherd, "Women and the Abolition Campaign in the African Atlantic," 142.
} 
of marriage, the slave breeding program, and the jurisdiction of the colonial-slave system. In sum, enslaved women's gynecological resistance involved resisting imperial programs to encourage slave marriages and sexual conformity as well as removing their bodies from the slavery system all together.

For enslaved women who did not have the luxury of upward mobility through interracial sex, the chance to escape the plantation, or the ability to resist sexual violence, the slave breeding project advocated by abolitionists and employed by slaveowners resulted in pregnancies. However, women's gynecological resistance continued after conception as they exercised agency over their bodies and their children throughout their pregnancies and the child-rearing process. Many women chose abortion and infanticide while some chose to keep their babies and deliver them under the care of Black midwives and engage in African child-rearing practices against the wishes of the slaveowners. Shepherd suggests that enslaved women understood the implications of the abolition of the slave trade and acted to free their "enchained wombs" by refusing to bear children who would become slaves themselves! ${ }^{18}$ Kenneth Morgan attests to the use of abortive agents or physical violence to induce self-abortion as well as the practice of maternal infanticide. Morgan claims that these desperate acts of resistance were understood within "their woeful condition of perpetual chattel slavery."19These women asserted control over their reproduction to prevent their children from living as slaves and robbed their owners of their "property." 20 These acts of resistance were often unnoticed by slaveowners as the reproduction rates among enslaved women in Jamaica was historically low due to the bodily and emotional damage caused by their tremendous workload and frequent abuse. ${ }^{21}$

Abortions and infanticides were difficult for slave owners to account for and are just as difficult for researchers to track as this form of resistance was silenced by the women themselves. On the other hand, a woman choosing to keep her child and cherish them is also a form of resistance in a society that systematically tore families apart for profit and discouraged familial bonds. When many of these women carried their children to term, they faced a choice of giving birth in their community with the aid of a midwife or in clinics operated by doctors hired by slave masters. Many women chose to deliver their babies in their communities against the advice of doctors who warned of unsafe conditions and poor midwife practices. ${ }^{22}$ Before slaveowners took a special interest in reproductive labour in the 1780 s, enslaved women and community members held a measure of

19 Kenneth Morgan, "Slave Women and Reproduction in Jamaica, C.1776-1834," History 91, no. 2 (2006): 244-252.

20 Morgan, "Slave Women and Reproduction in Jamaica," 245-246.

21 Morgan, "Slave Women and Reproduction in Jamaica," 252.

22 Turner, Contested Bodies, 14.

23 Turner, Contested Bodies, 14. 
autonomy having developed "autonomous social networks and customs around maternal and infant care. ${ }^{, 23}$ In choosing to rely on midwives and their community to successfully deliver their children, women exercised control over their bodies and challenged slaveowners' power over the process by choosing who can touch them and care for their bodies/reproductive health. $^{24}$

Lastly, following the birth of their children, enslaved women employed African child-rearing practices which involved nursing their children for two years, sometimes up to three or four years, which stalled their reproductive capacities. Morgan claims that a longer nursing period entailed longer lactation, which served as a natural means of contraception, "either through the physiological suppression of fertility in the mother by producing breast milk or through the social impact of constant nurturing of infants and consequent unavailability to men. ${ }^{, 25}$ Morgan suggests that long lactation periods and post-partum taboos against a mother's resumption of intercourse during the nursing period are "carry-overs from traditions in West African societies" and contributed to extensive birth-spacing practice among slaves. ${ }^{26}$ These practices protected enslaved mothers' as they were able to fend off rape, prevent further pregnancies, and attend to their children. Gynecological revolt is undertaken through many forms of resistance after conception, from abortion and infanticide to observing culturally informed maternal health and child-rearing practices that inhibit productive capacities. In the end, all these forms of resistance contributed to sabotaging the demographic goals of enslavers and abolitionists.

To conclude, during the Age of Abolition, enslaved women's reproductive capacities were increasingly significant to slaveowners, abolitionists, colonial economies/societies, and the empire itself. This essay has examined Jamaican and British Caribbean sources that argue the wombs of enslaved women in the Anglo-Caribbean colonies were sites of colonial power as well as sites of "gynecological revolt" as women exercised agency over their sexuality, pregnancy, childbirth experience, and child-rearing process. This essay has centred the female body in slavery scholarship to reveal that the womb is a significant symbol in the struggles over freedom and slavery. ${ }^{27}$ Despite its importance, women's bodily resistance is not privileged in narratives on slavery and abolition. While women have long participated in the armed struggles against slavery and colonialism and at times have been recognized in those efforts, by focusing on women's bodies/the womb as a site of resistance, this essay has deconstructed resistance beyond imaginings of the "armed, militaristic, physical, and triumphant" struggle "particularly resonant in the Caribbean" and privileged the feminine, unarmed, clandestine, sexual, bodily resistance as revolutionary. ${ }^{28}$

\footnotetext{
24 Turner, Contested Bodies, 149.

25 Morgan, "Slave Women and Reproduction in Jamaica," 243

26 Morgan, "Slave Women and Reproduction in Jamaica," 243-244.

27 Sasha Turner, "Slavery, Freedom, and Women's Bodies," Journal of Women's History 29, no. 1 (2017): 177

28 Marisa Fuentes, Dispossessed Lives: Enslaved Women, Violence and the Archive (Philadelphia: University of Pennsylvania, 2016), 10.
} 


\section{Works Cited}

Fuentes, Marisa. Dispossessed Lives: Enslaved Women, Violence and the Archive. Philadelphia: University of Pennsylvania, 2016.

Morgan, Jennifer L. Laboring Women: Reproduction and Gender in New World Slavery. Philadelphia: University of Pennsylvania Press, 2004.

Morgan, Kenneth. "Slave Women and Reproduction in Jamaica, C.1776-1834." History 91, no. 2 (2006): 1-252.

Paugh, Katherine. "The Curious Case of Mary Hylas: Wives, Slaves and the Limits of British Abolitionism," Slavery \& Abolition 35, no. 4 (October 2, 2014): 629-647.

Reddock, Rhoda E. "Women and Slavery in the Caribbean: A Feminist Perspective." Latin American Perspectives 12, no. 1 (January 1985): 69.

Shepherd, Verene A. "Women and the Abolition Campaign in the African Atlantic." The Journal of Caribbean History 42, no. 1 (2008): 139-142.

Turner, Sasha. Contested Bodies: Pregnancy, Childrearing, and Slavery in Jamaica. Philadelphia: University of Pennsylvania Press, 2017.

Turner, Sasha. "Home-grown Slaves: Women, Reproduction, and the Abolition of the Slave Trade, Jamaica 1788-1807." Journal of Women's History 23, no. 3 (2011): 23-43.

Turner, Sasha. "Slavery, Freedom, and Women's Bodies.” Journal of Women's History 29, no. 1 (2017): 177. 